\title{
RAIN-FED PLANTATIONS OF THE DOMESTICATED ZIZIPHUS MAURITIANA IN THE SAHEL: EFFECTS OF VARIETIES AND ROOTSTOCKS ON YIELDS AND FRUIT QUALITY
}

\author{
Ali IBRAHIM*1, Dov PASTERNAK ${ }^{2}$, Iro Dan GUIMBO ${ }^{3}$, Abdou Salam SAIDOU ${ }^{1}$, \\ Moustapha AMADOU ${ }^{1}$ \\ ${ }^{1}$ International Crops Research Institute for the Semi-Arid Tropics (ICRISAT) \\ P.O. Box 12404 Niamey, Niger \\ ${ }^{2}$ International Adviser Drylands Agriculture, 16/12 Harav Goren St., Rishon Letzion 75753, Israel \\ ${ }^{3}$ University of Tahoua, Niger
}

Received: May, 2015; Accepted: June, 2015

Edited by: M. Sitarek

\begin{abstract}
A long-term study was conducted to explore the possibility of using traditional rain-fed systems for growing domesticated Ziziphus mauritiana (so-called Pomme du Sahel) in the Sahel. Five varieties, Gola, Ben Gurion, Seb, Umran and Kaithli, were grafted on six rootstocks of $Z$. mauritiana from various agroecological zones of Niger. Trees were planted inside microcatchments at $8 \times 8 \mathrm{~m}$ spacing. Over a period of six years, the variety Umran gave the highest fruit yield $\left(3600 \mathrm{~kg} \cdot \mathrm{ha}^{-1}\right)$ and the lowest fruit yield was documented for variety Seb $\left(1970 \mathrm{~kg} \cdot \mathrm{ha}^{-1}\right)$. Individual fruit weight ranged from $25.8 \mathrm{~g}$ for 'Umran' to $9.5 \mathrm{~g}$ for 'Seb'. The rootstocks had no effect on average fruits yields and fruit size. There was a significant linear correlation between fruit yield and annual rainfall. In a rainy year $(680 \mathrm{~mm})$, the average yield of the five varieties was $7580 \mathrm{~kg} \cdot \mathrm{ha}^{-1}$. The results of the current study indicate that dry land plantations of Pomme du Sahel can guarantee food security during dry years in the Sahel. However, further studies are required to evaluate the economic feasibility of this system.
\end{abstract}

Key words: Pomme du Sahel, domestication, varieties, rootstocks

\section{INTRODUCTION}

The Sudano-Sahelian agro-pastoral system is characterized by a very low level of productivity of growing plants that results from an inherent poor soil and severe human induced land degradation. Fruit trees play an important role in the Sudano-Sahelian production system. The introduction of hardy, indigenous, high value fruit trees into the rain-fed production system of the Sudano-Sahel might help to break the poverty trap caused by current production systems (Leakey et al. 2005).

In the Sudano-Sahel, yields of annual crops are affected more by long dry spells between rains than by a total seasonal rainfall. At the same time yields of trees are more affected by the total amount of rainfall and less by the length of the dry spells. Sudano-Sahelian parkland trees are more drought tolerant than the annual crops due to their deeper and prolific root system and their xeromorphic anatomy. Many trees such as baobab (Adansonia digitata) or Ziziphus mauritiana are less affected by the long dry spell period because they shed their leaves and go dormant during this period. Growing trees in rainfed conditions ensures income and food in drought years when annual crops fail. Introduction of domesticated fruit trees to the tropics as a means for income generation has been advocated in many studies (Leakey 2001; Leakey \& Simons 1998; Leakey et al. 2005). 
Ziziphus mauritiana is a small tree commonly grown in the dry regions of Africa and South Asia (Pasternak et al. 2009). The tree is tolerant to drought, flooding, salinity and withering (Grice 1997; Hooda et al. 1990). In Africa, fruits of the wild Z. mauritiana are edible but they are small and hence their economic value is low. Z. mauritiana was domesticated in India and many varieties were developed (Vashishtha \& Pareek 1989). In India the tree is grafted on vigorous rootstocks such as Ziziphus rotundifolia (Lal \& Dhaka, 2007). Recently, study made in Mali aimed at adapting three improved cultivars of Ziziphus mauritiana from India to the Sudano-Sahelian farming conditions showed that improved cultivars grafted on suckers of local Ziziphus mauritiana resulted in a significantly better growth and higher fruit production compared with nursery seedling rootstocks (Sanou et al. 2014).

The current paper describes study carried out in Niger over a period of six years that aimed at creating a profitable rainfed fruit trees plantation. The objective of this study was to assess fruit yield and quality of five improved Ziziphus mauritiana varieties grafted on six rootstock genotypes of wild Z. mauritiana provenances.

\section{MATERIALS AND METHODS}

The study was conducted at the International Crops Research Institute for the Semi-Arid Tropics (ICRISAT) Sadoré research station in Niger $\left(13^{\circ} 15^{\prime} \mathrm{N}\right.$ and $2^{\circ} 18^{\prime} \mathrm{E}$ ). The climate is characterized by a rainy season that occurs between June and September, and a dry season that prevails during the rest of the year. The mean annual rainfall at Sadoré is $560 \mathrm{~mm}$ and the average temperature is $29^{\circ} \mathrm{C}$ (West et al. 1984).

In the period 2005-2009 annual rainfall varied from 450 to $550 \mathrm{~mm} \cdot$ year $^{-1}$ (Fig. 1). The year with exceptionally high rainfall was 2010 when total annual rainfall climbed to $680 \mathrm{~mm}$. Average annual rainfall for the six study years was $525 \mathrm{~mm}$.

The soil of the experimental site is classified as a sandy silicious isohyperthermic Psammentic Paleustalf (Soil Survey Staff 1999). The main characteristics of this soil are a high sand content, low native fertility with low organic matter and low cat- ion exchange capacity. This soil is generally very strongly acid to strongly acid ( $\mathrm{pH} 4.5-5.0$ ). Soil water content at field capacity is 0.09 to $0.10 \mathrm{~m}^{3} \cdot \mathrm{m}^{-3}$ (Klaij \& Vachaud 1992).

\section{Experimental details}

The rootstocks of Z. mauritiana from Ayerou, Birni N'Gaouré, Dosso, Gaya, Sadoré and Tillaberi were randomly planted in a field. The names of the rootstocks were based on the regions where they were collected (Table 1). A total of ninety rootstocks seedlings were planted at $8 \times 8 \mathrm{~m}$ spacing between trees. The rootstocks were three years old when grafted. Five varieties of Pomme du Sahel (Gola, Ben Gurion, Seb, Umran and Kaithli) introduced in Niger by the International Program for Arid Land Crops (IPALAC) were grafted in August 2001 on six rootstocks arranged in randomized complete block design and each grafted tree was replicated three times. The combination of rootstock and variety were considered as treatment giving therefore a total of $6 \times 5=30$ treatments.

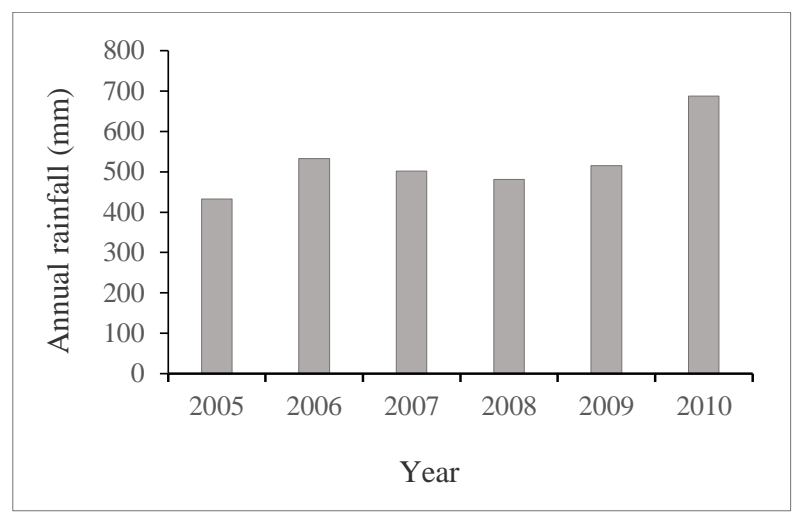

Fig. 1. Annual rainfall ( $\mathrm{mm}$ ) during the six experimental years

Table 1. Rootstocks provenances

\begin{tabular}{|c|c|c|}
\hline Location & $\begin{array}{l}\text { Rounded mean annual } \\
\text { rainfall }(\mathrm{mm})\end{array}$ & Coordinates \\
\hline Ayerou & 300 & $14^{\circ} 44^{\prime} \mathrm{N}$ and $0^{\circ} 55^{\prime} \mathrm{E}$ \\
\hline Tillabéry & 400 & $14^{\circ} 13^{\prime} \mathrm{N}$ and $1^{\circ} 27^{\prime} \mathrm{E}$ \\
\hline $\begin{array}{l}\text { Birni } \\
\text { N'Gaouré }\end{array}$ & 600 & $\begin{array}{c}13^{\circ} 5^{\prime} 16^{\prime \prime} \mathrm{N} \text { and } \\
2^{\circ} 55^{\prime} 1^{\prime \prime} \mathrm{E}\end{array}$ \\
\hline Sadoré & 550 & $13^{\circ} 15^{\prime} \mathrm{N}$ and $2^{\circ} 18^{\prime} \mathrm{E}$ \\
\hline Dosso & 650 & $13^{\prime} 03^{\prime} \mathrm{N}$ and $03^{\circ} 12^{\prime} \mathrm{E}$ \\
\hline Gaya & 800 & $\begin{array}{c}11^{\circ} 53^{\prime} 16^{\prime \prime} \mathrm{N} \text { and } \\
03^{\circ} 26^{\prime} 48^{\prime \prime} \mathrm{E} \\
\end{array}$ \\
\hline
\end{tabular}


A micro-catchment (half-moon shape) for collecting rainwater of 3 meters wide and 3 meters long was dug around each individual tree. The microcatchments were connected to each other by earth ridges that diverted run-off water into the microcatchments guaranteeing maximum water harvesting from the field.

Trees were pruned each year during the month of May just before the rainy season. In each pruning about $50 \%$ of the canopy was removed. At the same time each tree received $5 \mathrm{~kg}$ of composted cow manure and $200 \mathrm{~g}$ of NPK 15-15-15. Both the manure and the fertilizer were buried at a depth of $20 \mathrm{~cm}$ on two sides of the tree.

Fruits were sprayed each year with Decis (deltamethrin) against fruit flies (Carpomya incompleta), which are the dominant pests of Ziziphus fruit at Sadoré (Zakari-Moussa et al. 2012). A total of three sprays were done. First spray was applied when the fruits reached the size of a pea.

\section{Data collection}

Fruit yield was recorded for six consecutive years (2005-2010). Fruits were harvested when their color changed from green to yellow-green. The weight of individual fruit was taken and yield per tree was calculated. Shelf-life of the Pomme du Sahel fruit was determined in the last year of the study. Ten fruits from each variety were selected at the yellow green stage. The fruits were placed in an air conditioned room at $25{ }^{\circ} \mathrm{C}$ for a maximum of four days depending on the variety to determine the color change. The fruits were considered of low quality (but still edible) when the color changed from yellow-green to brown. Total soluble solids (TSS) content of yellow-green fruits was determined in the last year of the study using a refractometer (ERMA Hand Refractometer, Tokyo, Japan, Brix 0-32\%). The percent TSS was obtained from direct reading of the instrument.

\section{Statistical analysis}

The data collected were subjected to analysis of variance with GENSTAT v.9 (Lawes Agricultural Trust 2007) using a General Treatment Structure (in Randomized Blocks). It is worthy to note that because of some missing data throughout the experimental years, the analysis was carried out on a year by year basis. Since no significant interaction was obtained between the varieties and rootstocks, only the specific effects of variety and rootstock were presented in the current study. Wherever these specific effects were significant, the means were separated using the least significant difference (LSD) at 5\% probability level. Regression analysis was performed to establish the relationship between fruit yield and annual mean rainfall.

\section{RESULTS AND DISCUSSION}

\section{Effect of rootstocks and varieties on fruit yield}

The average fruit yield per variety (Table 2) was significantly different $(\mathrm{P}<0.05)$ over the sixyear period. Fruit yields ranged from $3603 \mathrm{~kg} \cdot \mathrm{ha}^{-1}$ for 'Umran' to $1974 \mathrm{~kg} \cdot \mathrm{ha}^{-1}$ for the 'Seb'. In 2007, 2008 and 2009 there was a significant difference $(\mathrm{P}<0.05)$ in fruit yield among varieties. Even though the effect of year was not captured in the current study, the fruit yields were markedly different between the years. The highest fruit yield $\left(7584 \mathrm{~kg} \cdot \mathrm{ha}^{-1}\right)$ was obtained in 2010 and lowest $\left(1094 \mathrm{~kg} \cdot \mathrm{ha}^{-1}\right)$ in 2006 , which can be attributed to the highest rainfall recorded in 2010 (Fig. 1). In arid or semi-arid areas, mature Ziziphus trees require at least $600 \mathrm{~mm}$ of water for optimal production (Arora et al. 2002). In the current study this requirement was satisfied only in 2010. This result is consistent with an earlier study which demonstrated that supply of adequate amount of water increased the fruit weight and total fruit yield of Ziziphus jujube, a relative of Ziziphus mauritiana (Ismail \& Almarshadi 2013).

There was a significant positive correlation $(\mathrm{P}<0.05)$ between fruit yield and rainfall (Fig. 2). It is apparent from this figure that the relationship between rain and fruit yield was linear. For every increase in $100 \mathrm{~mm}$ of annual rain above $400 \mathrm{~mm}$ per year there was an increase of approximately $2500 \mathrm{~kg} \cdot \mathrm{ha}^{-1}$ in fruit yield.

Fruit yields were significantly different among the rootstocks in all the experimental years, except for 2010 (Table 3). From 2005 to 2009, Sadoré and Tillabéry rootstocks gave the highest fruit yields. There was no significant difference in yields among the rootstocks when yields were averaged over a six-year period. There were marked annual variations in fresh fruit yield between the different rootstocks. The lowest yield was recorded in 2005 and highest in 2010 year. 
Table 2. Effect of five varieties of Ziziphus mauritiana on fruit yield $\left(\mathrm{kg} \cdot \mathrm{ha}{ }^{-1} \pm \mathrm{SE}\right)$ over a six-year period

\begin{tabular}{lccccccc}
\hline Varieties & 2005 & 2006 & 2007 & 2008 & 2009 & 2010 \\
\cline { 2 - 7 } Ben Gurion & $2231 \pm 555$ & $1181 \pm 309$ & $4964 \mathrm{a} \pm 1123$ & $1398 \mathrm{~b} \pm 577$ & $1816 \mathrm{~b} \pm 764$ & $6770 \mathrm{~b} \pm 1201$ & $3060 \mathrm{ab}$ \\
Gola & $1223 \pm 388$ & $888 \pm 137$ & $4348 \mathrm{ab} \pm 483$ & $2022 \mathrm{a} \pm 359$ & $3373 \mathrm{a} \pm 421$ & $8596 \mathrm{a} \pm 1404$ & $3408 \mathrm{a}$ \\
Kaithli & $969 \pm 452$ & $1150 \pm 192$ & $2792 \mathrm{bc} \pm 608$ & $1533 \mathrm{~b} \pm 483$ & $1934 \mathrm{~b} \pm 483$ & $6848 \mathrm{~b} \pm 2090$ \\
Seb & $1173 \pm 613$ & $1290 \pm 243$ & $1839 \mathrm{c} \pm 748$ & $674 \mathrm{c} \pm 483$ & $1022 \mathrm{~b} \pm 624$ & $5846 \mathrm{~b} \pm 2059$ & $2538 \mathrm{~b}$ \\
Umran & $924 \pm 376$ & $964 \pm 154$ & $3716 \mathrm{~b} \pm 468$ & $2703 \mathrm{a} \pm 406$ & $3452 \mathrm{a} \pm 452$ & $9859 \mathrm{a} \pm 1872$ \\
\hline Average yield/year & 1304 & 1094 & 3532 & 1666 & 2319 & 7584 \\
$p$ & 0.071 & 0.559 & 0.033 & 0.029 & 0.004 & 0.235 \\
\hline
\end{tabular}

\pm Standard error. Means within the same column and row followed with the same letters are not significantly different according to LSD test at $\mathrm{P}<0.05$.

Effect of varieties and rootstocks on one fruit weight

There were significant differences in the weight of one fruit among varieties. 'Seb' had the lowest fruit weight, whereas 'Umran' recorded the highest fruit weight (Table 4). A number of studies assessing the performance of improved Ziziphus mauritiana varieties also found that Umran variety had the greatest fruit weight as compared to other improved varieties (Aulakh et al. 2005; Ghosh \& Mathew 2002). Rootstocks had no significant effect on the weight of individual fruit.

\section{Shelf-life and total soluble solids (TSS) of Pomme du Sahel (PDS) varieties}

A shelf-life of five Pomme du Sahel varieties is presented on Fig. 3. The color started changing from the first day of storage. 'Kaithli' was the only variety that did not start changing color after two days. In all the varieties the color changed fully within 4 days of

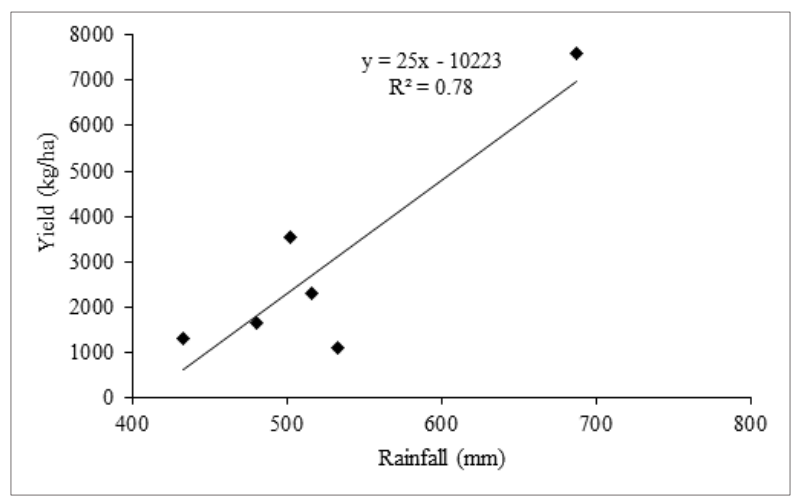

Fig. 2. Relationship between annual rainfall and yield of Ziziphus mauritiana varieties storage at $25{ }^{\circ} \mathrm{C}$. Short shelf-life is a major problem for Pomme du Sahel fruits. Cooling is a good way for extending shelf-life of this fruit. Earlier study by Jawanda et al. (1980) showed that fruits dipped for 30 sec in waxes and stored in perforated polyethylene bags extends the shelf-life to 10-12 days. Fruits cooling at 3 to $5{ }^{\circ} \mathrm{C}$ can extend shelf-life beyond 14 or 21 days depending on the variety (Pareek et al. 2009). However, cooling conditions are not available in most places in dry Africa. Storage in polyethylene bags also improves shelf-life (Jawanda et al. 1980) and this technology can be implemented in Africa.

The TSS of 'Seb' was the lowest out of the five tested varieties and 'Gola' and 'Umran' had the highest TSS (Fig. 4). 'Gola' had relatively high yield, big fruits and a high TSS (Baloda et al. 2012), which is confirmed in this research also, but it was found to be particularly sensitive to the Ziziphus fruit fly and for this reason it was discarded.

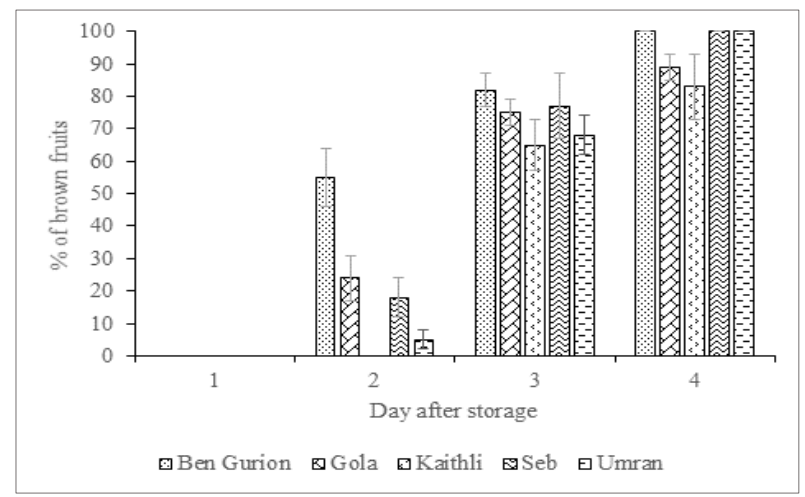

Fig. 3. Effect of variety of Ziziphus mauritiana on fruits shelf-life (bar denoted the standard error) 
Table 3. Effect of six rootstocks on fruit yield $\left(\mathrm{kg} \cdot \mathrm{ha}^{-1} \pm \mathrm{SE}\right)$ of Ziziphus mauritiana over a six-year period

\begin{tabular}{|c|c|c|c|c|c|c|c|}
\hline Rootstocks & 2005 & 2006 & 2007 & 2008 & 2009 & 2010 & $\begin{array}{l}\text { Average } \\
\text { yield/root } \\
\text { stock }\end{array}$ \\
\hline Ayerou & $1438 a \pm 384$ & $671 c \pm 187$ & $3997 b \pm 608$ & $1794 c \pm 530$ & $2851 \mathrm{c} \pm 624$ & $9407 a \pm 1794$ & 3360 \\
\hline Birni N'Gaouré & $541 \mathrm{c} \pm 308$ & $950 \mathrm{bc} \pm 163$ & $3432 b c \pm 530$ & $1654 c \pm 468$ & $2761 \mathrm{c} \pm 546$ & $7117 b \pm 1606$ & 2742 \\
\hline Dosso & $482 c \pm 348$ & $1087 b \pm 178$ & $4649 b \pm 577$ & $2012 b c \pm 499$ & $3073 c \pm 593$ & $8502 a \pm 1529$ & 3301 \\
\hline Gaya & $1005 b \pm 470$ & $856 c \pm 240$ & $3058 c \pm 780$ & $2215 b c \pm 686$ & $2917 \mathrm{c} \pm 795$ & $6209 b \pm 2293$ & 2700 \\
\hline Sadoré & $635 c \pm 347$ & $1159 a b \pm 178$ & $4477 b \pm 733$ & $3229 a \pm 499$ & $4493 a \pm 593$ & $9329 a \pm 1685$ & 3886 \\
\hline Tillabéry & $1465 \pm 332$ & $1426 \pm 170$ & $5725 \pm 936$ & $2465 \pm 484$ & $3806 \pm 561$ & $9563 \pm 1685$ & 4075 \\
\hline $\begin{array}{l}\text { Average } \\
\text { yield/year }\end{array}$ & 928 & 1025 & 4223 & 2228 & 3316 & 8355 & \\
\hline$p$ & 0.005 & $<.001$ & $<.001$ & $<.001$ & $<.001$ & 0.746 & 0.583 \\
\hline
\end{tabular}

\pm Standard error. Means within the same row followed with the same letters are not significantly different according to LSD test at $\mathrm{P}<0.05$.

\section{CONCLUSION}

The dry land plantation of Pomme du Sahel gives an alternative for diversifying rain-fed crop production in the Sahel. Fruit yield is highly variable between varieties. The Umran variety produced the highest yield whereas 'Seb' had the lowest. The rootstocks did not significantly affect fruit yield and fruit weight when averaged over the six years period. The identification of rootstocks for improving fruit yields of domesticated Z. mauritiana in the Sahel should be therefore continued. The evidence

Table 4. Effect of variety and rootstock of Ziziphus mauritiana on average fruit weight

\begin{tabular}{lclc}
\hline \multicolumn{1}{c}{ Varieties } & $\begin{array}{c}\text { Fruit weight } \\
(\mathrm{g})\end{array}$ & \multicolumn{1}{c}{ Rootstocks } & $\begin{array}{c}\text { Fruit } \\
\text { weight }(\mathrm{g})\end{array}$ \\
\hline Ben Gurion & $13.2 \mathrm{~b} \pm 1.6$ & Ayerou & $15.8 \pm 1.7$ \\
Gola & $13.5 \mathrm{~b} \pm 1.4$ & Birni N'Gaouré & $15.3 \pm 3.0$ \\
Kaithli & $22.2 \mathrm{a} \pm 4.1$ & Dosso & $16.2 \pm 2.4$ \\
Seb & $9.5 \mathrm{c} \pm 1.7$ & Gaya & $17.8 \pm 3.9$ \\
Umran & $25.8 \mathrm{a} \pm 3.6$ & Sadoré & $14.3 \pm 1.9$ \\
& & Tillabéry & $17.6 \pm 2,9$ \\
F. prob. & $<.001$ & F. prob. & 0.936 \\
\hline
\end{tabular}

\pm Standard error. Means within the same column followed with the same letters are not significantly different at $\mathrm{P}<0.05$. from the current study indicates that the introduction of rainfed fruit trees plantations based on the improved varieties of Ziziphus mauritiana to the traditional rainfed production system of the Sahel can improve people nutrition and secure food in drought years. However, the economic feasibility of this system still needs verification.

\section{Acknowledgment}

The authors would like to thank the staff of the Crops and Systems Diversification Program at ICRISAT-Niger for helping in data collection and processing and also to the Finland Ministry of Foreign for the financial support.

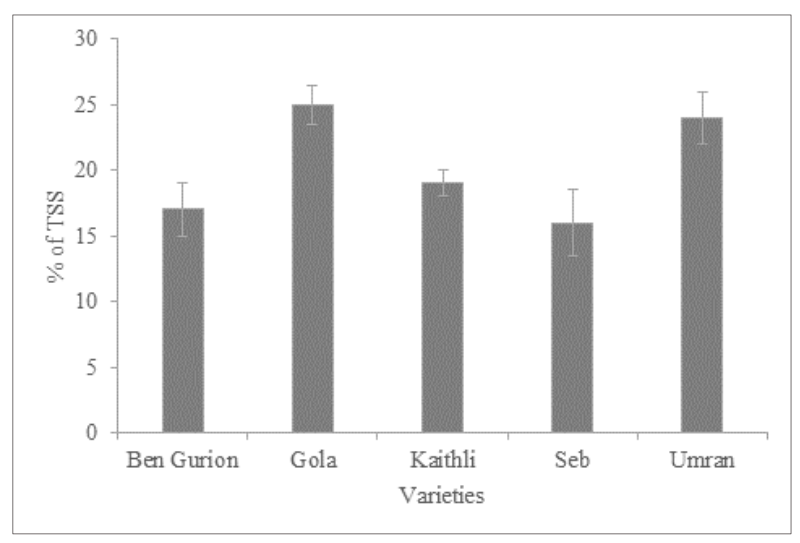

Fig. 4. Effect of variety of Ziziphus mauritiana on content of total soluble solids (bars represent \pm standard errors) 


\section{REFERENCES}

Arora R., Azam-Ali S., Clement C., Haq N., Hughes A., Schreckenberg K., Simons A., Smith R. 2002. Fruits for the Future 2: Ber Ziziphus mauritiana Lam. Field manual for Extension Workers. Crops for the Future.

Aulakh P., Vij V., Kumar A. 2005. Comparative performance of some promising ber varieties grown under arid-irrigated conditions of Punjab. Indian Journal of Horticulture 62(2): 127-128.

Baloda S., Sehrawat S.K., Yadav B.S., Ahlawat V.P., Singh S. 2012. Present status of ber production and future thrusts in India - A review. Agricultural Reviews 33(3): 256-264.

Ghosh S.N., Mathew B. 2002. Performance of nine ber (Ziziphus mauritiana Lamk) cultivars on topworking in the semi-arid region of West Bengal. Journal of Applied Horticulture 4(1): 49-51.

Grice A.C. 1997. Post-fire regrowth and survival of the invasive tropical shrubs Cryptostegia grandiflora and Ziziphus mauritiana. Australian Journal of Ecology 22(1): 49-55. DOI: 10.1111/j.14429993.1997.tb00640.x.

Hooda P.S., Sindhu S.S., Mehta P.K., Ahlawat V.P. 1990. Growth, yield and quality of ber (Zizyphus mauritiana Lamk.) as affected by soil salinity. The Journal of Horticultural Science \& Biotechnology 65(5): 589-593.

Ismail S.M., Almarshadi M.H.S. 2013. Effect of water distribution patterns on productivity, fruit quality and water use efficiency of Ziziphus jujuba in arid regions under drip irrigation system. Journal of Food, Agriculture and Environment 11(1): 373-378.

Jawanda J.S., Bal J.S., Josan J.S, Mann S.S. 1980. Studies on the storage of ber fruits. I. Room temperature. Punjab Horticultural Journal 20(1/2): 55-61.

Klaij M.C., Vachaud G. 1992. Seasonal water balance of a sandy soil in Niger cropped with pearl millet, based on profile moisture measurements. Agricultural Water Management 21(4): 313-330. DOI: 10.1016/0378-3774(92)90053-Y.

Lal G., Dhaka R. 2007. Effect of different rootstocks on growth, yield and quality of ber (Ziziphus mauritiana Lamk.) cv. Umran and Gola. Annals of Arid Zone 46: 107.
Leakey R.R.B. 2001. Win: Win landuse strategies for Africa: 2. Capturing economic and environmental benefits with multistrata agroforests. The International Forestry Review 3: 11-18.

Leakey R.R.B., Simons A.J. 1998. The domestication and commercialization of indigenous trees in agroforestry for the alleviation of poverty. Agroforestry Systems 38: 165-176. DOI: 10.1023/A:1005912729225.

Leakey R.R.B., Tchoundjeu Z., Schreckenberg K., Shackleton S.E., Shackleton C.M. 2005. Agroforestry tree products (AFTPs): targeting poverty reduction and enhanced livelihoods. International Journal of Agricultural Sustainability 3(1): 1-23. DOI: $10.1080 / 14735903.2005 .9684741$.

Pareek S., Kitinoja L., Kaushik R.A., Paliwal R. 2009. Postharvest physiology and storage of ber. Stewart Postharvest Review 5(5): 1-10. DOI: 10.2212/spr.2009.5.5.

Pasternak D., Senbeto D., Nikiema A., Kumar S., Fatondji D., Woltering L., Ratnadass A., Ndjeunga J. 2009. Bioreclamation of degraded African lands with women empowerment. Chronica Horticulturae 49(2): 24-27.

Sanou H., Sidibé D., Korbo A., Teklehaimanot Z. 2014. Rootstock propagation methods affect the growth and productivity of three improved cultivars of ber in Mali, West Africa. HortTechnology 24(4): 418-423.

Soil Survey Staff 1999. Soil Taxonomy: A Basic System of Soil Classification for Making and Interpreting Soil Surveys, 2nd edn, U.S. Department of Agriculture Handbook 436. Washington, DC: USDA Natural Resources Conservation Service.

Vashishtha B., Pareek O. 1989. Identification key for the cultivars of Indian jujube (Ziziphus mauritiana Lamk.). Indian Journal of Horticulture 46(2): 183-188.

West L.T., Wilding L.P., Landeck J.K., Calhoun F.G. 1984. Soil survey of the ICRISAT Sahelian center, Niger, West Africa. Texas A \& M University. pp. 82.

Zakari-Moussa O., Ratnadass A., Vayssières J.-F., Nikiema A., Fatondji D., Salha H., Aboubacar K., Ryckewaert P., Pasternak D. 2012. GF-120 effects on fruit fly species (Diptera: Tephritidae) in Sahelian agroforestry-based horticultural cropping systems. Fruits 67(5): 333-339. DOI: 10.1051/fruits/2012025. 